\title{
32. PETROLOGY AND GEOCHEMISTRY OF BASALTS FROM DEEP SEA DRILLING PROJECT LEG 86, SITE 581'
}

\author{
John C. Fountain, Robert D. Jacobi, and Timothy J. Fahey, State University of New York at Buffalo²
}

\begin{abstract}
Approximately $5 \mathrm{~m}$ of aphyric to sparsely phyric basalt was recovered from Hole 581 , the only hole on Leg 86 where basement was cored. The occurrence of samples with altered glassy rinds indicates that at least three cooling units (pillows or thin flows) were sampled. The samples were moderately to intensely altered; groundmass crystals are generally fresh, but all glass is altered. Alteration is greatest in vesicular samples, but most of the samples have fractures filled with iron oxyhydroxide, clay, and/or calcite.

All 13 samples analyzed are moderately fractionated aluminous $\mathrm{N}$-type mid-ocean ridge basalts. The samples can be divided into two groups based on $\mathrm{TiO}_{2}$ and $\mathrm{FeO}$ contents. The least-evolved group may be derived from a more primitive mid-ocean ridge basalt by the crystallization of $18 \%$ plagioclase, $24 \%$ clinopyroxene, and $3 \%$ olivine. The more evolved group may be derived from the first group by the fractionation of $18 \%$ plagioclase, $11 \%$ clinopyroxene, and $3 \%$ olivine. However, higher $\mathrm{Ce} / \mathrm{Yb}$ ratios in the more evolved group cannot be produced by fractionation and thus we must invoke a more complex process such as dynamic melting to relate the two groups to a common source.
\end{abstract}

\section{INTRODUCTION}

Igneous basement was cored in only one hole on Deep Sea Drilling Project (DSDP) Leg 86, at Site 581 (Fig. 1). On the basis of magnetic lineations at this site, the basement age has been estimated to be 116 m.y. (see Site 581 chapter, this volume). Southwest of Site 581, slightly older basalts were recovered at Sites 303, 304, and 307 during Leg 32 (Marshall, 1975). The crust at both Site 581 and the Leg 32 sites was generated by the Japanese spreading center, which has since been subducted (Larson and Chase, 1972). The three Leg 32 sites provide the only published data on the composition of ridge-generated basaltic ocean crust in the Northwest Pacific.

Site 581 was drilled again on Leg 88 (Holes 581A, $581 \mathrm{~B}$, and $581 \mathrm{C}$ ) and more basalt was recovered. This chapter includes data only for the Leg 86 samples (Hole 581).

Cores recovered from Site 581 include about $5 \mathrm{~m}$ of aphyric to sparsely phyric basalt in Core 19 , from a subbottom depth of about $343 \mathrm{~m}$. Several vesicular samples with altered glassy rinds and fine-grained interiors were recovered from the central portion of this core; elsewhere the samples were generally fine grained. The presence of samples with chilled rinds suggests that at least three cooling units were sampled; J. Natland, from examination of other samples of this core, has identified at least eight cooling units (J. Natland, written communication, 1984). Representative samples, spanning the entire igneous portion of the core, were examined in thin section

\footnotetext{
${ }^{1}$ Heath, G. R., Burckle, L. H., et al., Init. Repts. DSDP, 86: Washington (U.S. Govt. Printing Office).

2 Address: (Fountain, Jacobi, Fahey) Department of Geological Sciences, State University of New York at Buffalo, 4240 Ridge Lea Road, Amherst, NY 14226.
}

and analyzed for major-element composition and for selected trace-element abundances.

\section{EXPERIMENTAL METHODS}

Abundances of major elements were determined using the U.S. Geological Survey (USGS) "rapid" analysis techniques (Shapiro, 1975). Accuracy and precision of these analyses have been reported by Clemency and Borden (1978). Concentrations of rare-earth elements were determined by isotope-dilution mass spectrometry on a 12 -in. radiusof-curvature National Bureau of Standards-type mass spectrometer. Samples were dissolved with lithium metaborate and the rare-earth elements isolated by ion exchange using procedures developed at State University of New York, Stony Brook (Vocke, 1983). Precision of rareearth element determinations is better than $2 \%$.

Abundances of all other trace elements were determined by X-ray fluorescence using pressed-powder pellets. Empirical matrix-correction factors were derived from a suite of international reference standards.

\section{RESULTS}

The samples from Hole 581 are aphyric to sparsely phyric tholeiitic basalts. Plagioclase (An 65-70) is the most common microphenocryst (Table 1). Augite microphenocrysts are present in a few samples, while olivine microphenocrysts are rare. Minor amounts of iddingsite, presumably a product of the alteration of olivine, were found in most samples, but there is no evidence that olivine was a major phenocryst phase in any sample.

Groundmass crystals are generally fresh; however, the high water contents and high ferric iron to ferrous iron ratios indicate that all samples have been significantly altered. Alteration is greatest in vesicular samples, but most of the samples have fractures filled with iron oxyhydroxide, clay, and/or calcite. These veins are extensive in several samples, contributing several percent to their bulk composition.

Chemical analyses were performed on the least-altered portions of each sample; generally only the interior por- 


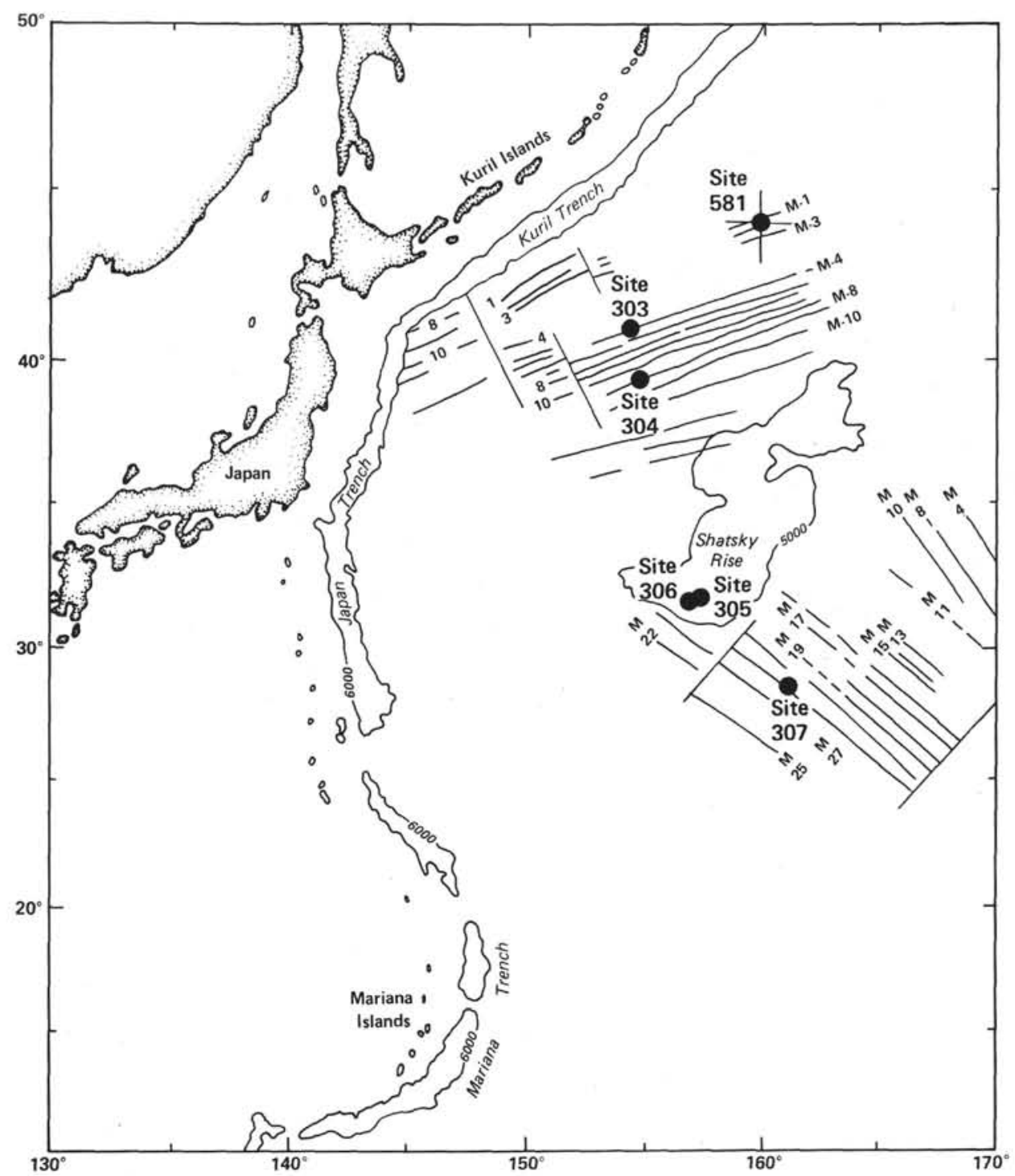

Figure 1. Chart of the northwestern Pacific showing the location of Leg 86 Site 581 and Leg 32 Sites 303 , $304,305,306$, and 307 , magnetic lineations and major physiographic features. From Moberly and Larson (1975).

tions of the samples were analyzed since the glassy margins were significantly altered.

The major-element compositions of the samples are typical for slightly fractionated mid-ocean ridge basalts (MORBs), with slightly higher than average $\mathrm{Al}_{2} \mathrm{O}_{3}$ contents (Table 2). The samples can be divided into two distinct groups based on composition. Group I consists of Samples A and B (the uppermost samples in the core); Group II includes the other 11 samples. The Group II samples are very similar in composition, considering the extent of alteration of the samples. Group I samples have lower levels of $\mathrm{TiO}_{2}, \mathrm{FeO}^{*}$, and $\mathrm{P}_{2} \mathrm{O}_{5}$, and hence are more primitive than Group II samples. There are no systematic variations in composition within Group II. Elements with similar geochemical behavior do not show parallel variations, nor is there any regularity in variation in composition with stratigraphic position within the group. The lack of coherence among elements in Group II samples indicates that any variation in composition due to magmatic differentiation is so small that it either is obscured by alteration or is less than the precision of the analyses.

All samples analyzed show typical N-type MORB lightrare-earth element depletion (Fig. 2), and all are within the range of N-type MORBs reported by Sun et al. (1979). The Group I samples have lower rare-earth element abundances and a lower $\mathrm{Ce} / \mathrm{Yb}$ ratio than the more evolved Group II samples. As with the major elements, all Group II samples have similar rare-earth element abundances.

The distribution of $\mathrm{Ni}, \mathrm{Cr}, \mathrm{Zr}$, and $\mathrm{Rb}$ is also consistent with the previously developed hypothesis that Group I samples are more primitive than Group II samples. The incompatible elements $\mathrm{Zr}$ and $\mathrm{Rb}$ are higher in Group II samples, while the compatible elements $\mathrm{Ni}$ and $\mathrm{Cr}$ are higher in the more primitive Group I samples. The average $\mathrm{Sr}$ content of Group I is lower than the average of Group II samples; however, the range of the two groups 
Table 1. Petrographic summary of samples from Hole 581, DSDP Leg 86.

\begin{tabular}{ccc}
\hline Sample & DSDP sample no. & $\begin{array}{c}\text { Description } \\
\text { A }\end{array} \quad$ 581-19-1, 23-27 cm \\
B & $\begin{array}{c}\text { Aphanatic basalt with sparse plagioclase } \\
\text { microphenocrysts and one olivine } \\
\text { microphenocryst. Intersertal devitri- } \\
\text { fied brown glass contains } \sim 15 \%\end{array}$ \\
plagioclase microlites.
\end{tabular}

Note: The glass in all samples was altered, and most samples contained minor iddingsite. Note that the sample designation used in this study (A-M) is arranged by increasing depth in the core.

overlaps. The considerable range in the $\mathrm{Sr}$ and $\mathrm{Rb}$ abundances is much greater than that of other trace elements and thus is most likely due to alteration.

\section{DISCUSSION}

Comparison of Group I and Group II samples shows exactly the differences expected from low-pressure fractionation (Clague and Bunch, 1976, and the references therein). Since the stratigraphically highest samples (and hence presumably the youngest) are the least fractionated, it is unlikely that the entire suite of samples were derived by fractionation of a single magma batch. Furthermore, there are no large phenocrysts in the suite.
Calculation of major-element fractional crystallization models (Table 3 ) indicates that a magma with the composition of an average Group II sample can be derived from a magma of Group I composition by the removal of $18 \%$ plagioclase, $10 \%$ clinopyroxene, and $3 \%$ olivine. Plagioclase and pyroxene are also the most abundant microphenocrysts in the suite. Similar results have been reported for other fractionated MORB suites (Clague and Bunch, 1976; Mattey and Muir, 1980).

The Group I samples clearly have also undergone significant fractionation prior to their eruption. Model results indicate that a magma of the composition of Group I could be derived from the least-evolved basalt associated with the Siqueros Fracture Zone (an area with a well-documented ferrobasalt suite; Batiza et al., 1977) by the removal of $3 \%$ olivine, $24 \%$ augite, and $18 \%$ plagioclase (Table 3 ).

In view of the extent of alteration of our samples, the numerical solutions to the fractional crystallization models are not as significant as the general pattern of fractionation. Alteration has clearly affected the major-element compositions, and relatively small changes in the composition of the parent and daughter compositions used in a least-squares fractionation model can produce comparatively large changes in the calculated models.

To investigate the variation in model results caused by the alteration of the samples, models for the derivation of each of the samples in Group II were calculated. Models with acceptable correspondence could not be calculated for all flows. Samples with high $\mathrm{CaO}$ generally could not be modeled successfully because of large errors in the calculated $\mathrm{Ca}$ content since both plagioclase and clinopyroxene have high $\mathrm{Ca}$ contents. The proportion of plagioclase to pyroxene in the calculated models varied from about $1: 1$ to $2: 1$ as the olivine component increased. Olivine was never a major fractionating phase because removal of olivine results in rapid $\mathrm{MgO}$ depletion. The extent of $\mathrm{MgO}$ depletion is reduced if plagioclase (a MgO-free phase) is also removed. However, calculations indicate that no more than $5 \%$ olivine removal can be involved in the evolution of any of the Group II samples from a magma of Group I composition.

The extent of crystallization required by the models is dependent on all oxides. However, since $\mathrm{TiO}_{2}$ shows the largest relative change between the groups and is highly resistant to alteration, the fit of $\mathrm{TiO}_{2}$ was considered the best indicator of fractionation. Since $\mathrm{TiO}_{2}$ increased by between 30 and $40 \%$ between Groups I and II, a minimum 20 to $30 \%$ crystallization is required to derive the Group II compositions.

Trace-element variations between Group I and Group II are generally qualitatively consistent with the fractional crystallization model derived from the major-element abundances, but the increase in $\mathrm{Ce} / \mathrm{Yb}$ ratio between Groups I and II is not. Because $\mathrm{Ce}$ and $\mathrm{Yb}$ crystal/liquid partition coefficients are small, fractional crystallization will not induce large changes in the $\mathrm{Ce} / \mathrm{Yb}$ ratio (Gast, 1968, Langmuir et al., 1977). In typical fractionated MORB suites, rare-earth element abundances increase smoothly with fractionation, with little change in the $\mathrm{Ce} / \mathrm{Yb}$ ratio (Schilling et al., 1976; Humphris et al., 
J. C. FOUNTAIN, R. D. JACOBI, T. J. FAHEY

Table 2. Chemical analyses of basalt samples from DSDP Leg 86, Hole 581.

\begin{tabular}{|c|c|c|c|c|c|c|c|c|c|c|c|c|c|}
\hline $\begin{array}{c}\text { Oxide } \\
(\%)\end{array}$ & A & B & C & D & E & F & G & H & I & $\mathrm{J}$ & K & L & M \\
\hline $\mathrm{SiO}_{2}$ & 49.94 & 50.16 & 49.81 & 49.45 & 49.68 & 50.07 & 49.94 & 49.81 & 50.47 & 49.90 & 49.91 & 49.05 & 49.19 \\
\hline $\mathrm{TiO}_{2}$ & 1.33 & 1.34 & 1.83 & 1.74 & 1.82 & 1.81 & 1.85 & 1.76 & 1.81 & 1.82 & 1.79 & 1.84 & 1.79 \\
\hline $\mathrm{Al}_{2} \mathrm{O}_{3}$ & 16.12 & 16.17 & 15.85 & 15.53 & 15.61 & 15.85 & 15.89 & 15.38 & 16.22 & 15.75 & 15.85 & 16.51 & 15.52 \\
\hline $\mathrm{Fe}_{2} \mathrm{O}_{3}$ & 4.26 & 3.64 & 5.11 & 5.37 & 4.95 & 4.25 & 5.42 & 5.38 & 4.79 & 3.72 & 3.95 & 4.94 & 5.26 \\
\hline $\mathrm{FeO}$ & 4.37 & 4.43 & 4.92 & 5.93 & 5.76 & 4.99 & 4.25 & 5.12 & 4.97 & 5.36 & 4.67 & 4.71 & 4.66 \\
\hline $\mathrm{MnO}$ & 0.15 & 0.15 & 0.21 & 0.22 & 0.21 & 0.19 & 0.17 & 0.21 & 0.19 & 0.18 & 0.20 & 0.22 & 0.15 \\
\hline $\mathrm{MgO}$ & 8.15 & 8.38 & 7.36 & 7.08 & 7.32 & 7.62 & 7.26 & 7.02 & 7.36 & 7.68 & 8.18 & 7.92 & 7.64 \\
\hline $\mathrm{CaO}$ & 10.85 & 11.01 & 10.40 & 10.58 & 10.05 & 10.79 & 9.66 & 10.91 & 10.66 & 11.03 & 10.71 & 9.66 & 10.54 \\
\hline $\mathrm{Na}_{2} \mathrm{O}$ & 2.85 & 2.77 & 2.98 & 2.89 & 3.02 & 2.98 & 3.13 & 2.83 & 3.01 & 2.93 & 3.00 & 3.01 & 2.92 \\
\hline $\mathrm{K}_{2} \mathrm{O}$ & 0.30 & 0.20 & 0.36 & 0.48 & 0.49 & 0.30 & 0.53 & 0.55 & 0.36 & 0.22 & 0.12 & 0.17 & 0.33 \\
\hline $\mathrm{P}_{2} \mathrm{O}_{5}$ & 0.11 & 0.10 & 0.17 & 0.16 & 0.16 & 0.17 & 0.19 & 0.17 & 0.18 & 0.17 & 0.17 & 0.17 & 0.18 \\
\hline $\mathrm{H}_{2} \mathrm{O}^{+}$ & 2.15 & 2.05 & 2.05 & nd & 1.97 & 1.87 & 2.41 & 1.99 & nd & 1.89 & 2.23 & 2.27 & 2.19 \\
\hline $\mathrm{CO}_{2}$ & 0.09 & 0.08 & 0.08 & 0.04 & 0.05 & 0.08 & 0.11 & 0.05 & 0.07 & 0.03 & 0.43 & 0.10 & 0.13 \\
\hline $\mathrm{Mg}^{\prime}$ & 64 & 66 & 58 & 54 & 56 & 61 & 59 & 56 & 59 & 61 & 64 & 61 & 59 \\
\hline \multicolumn{14}{|c|}{ Trace-element abundance (ppm) } \\
\hline $\mathrm{Cr}$ & 335 & 335 & 258 & 255 & 269 & 257 & 242 & 259 & 268 & 246 & 236 & 262 & 231 \\
\hline $\mathrm{Sr}$ & 108 & 126 & 123 & 108 & 135 & 140 & 128 & 124 & 112 & 128 & 131 & 141 & 135 \\
\hline $\mathrm{Zr}$ & 70 & 75 & 101 & 99 & 112 & 112 & 113 & 106 & 103 & 119 & 111 & 103 & 102 \\
\hline $\mathrm{Rb}$ & 1 & 1 & 5 & 8 & 9 & 2 & 10 & 6 & 3 & 1 & 1 & 4 & 1 \\
\hline $\mathrm{Ni}$ & 115 & 113 & 100 & 79 & 106 & 99 & 101 & 90 & 88 & 93 & 202 & 102 & 104 \\
\hline $\mathrm{Ce}$ & & 7.1 & 12.4 & 11.6 & & & & & 12.5 & & & & \\
\hline $\mathrm{Nd}$ & & 7.7 & 11.7 & 11.2 & & & & & 11.7 & & & & \\
\hline Sm & & 2.9 & 4.0 & 3.9 & & & & & 3.9 & & & & \\
\hline Eu & & 1.1 & 1.5 & 1.4 & & & & & 1.5 & & & & \\
\hline Dy & & 5.3 & 7.0 & 6.9 & & & & & 7.2 & & & & \\
\hline $\mathrm{Er}$ & & 3.3 & 4.4 & 4.4 & & & & & 4.6 & & & & \\
\hline $\mathrm{Yb}$ & & 3.4 & 4.6 & 4.4 & & & & & 4.7 & & & & \\
\hline
\end{tabular}

Note: Sample numbers from Table $1 . \mathrm{Mg}^{\prime}=$ atomic ratio $\mathrm{Mg} /(\mathrm{Mg}+\mathrm{Fe}), \mathrm{Fe}=$ total iron as $\mathrm{FeO}$.

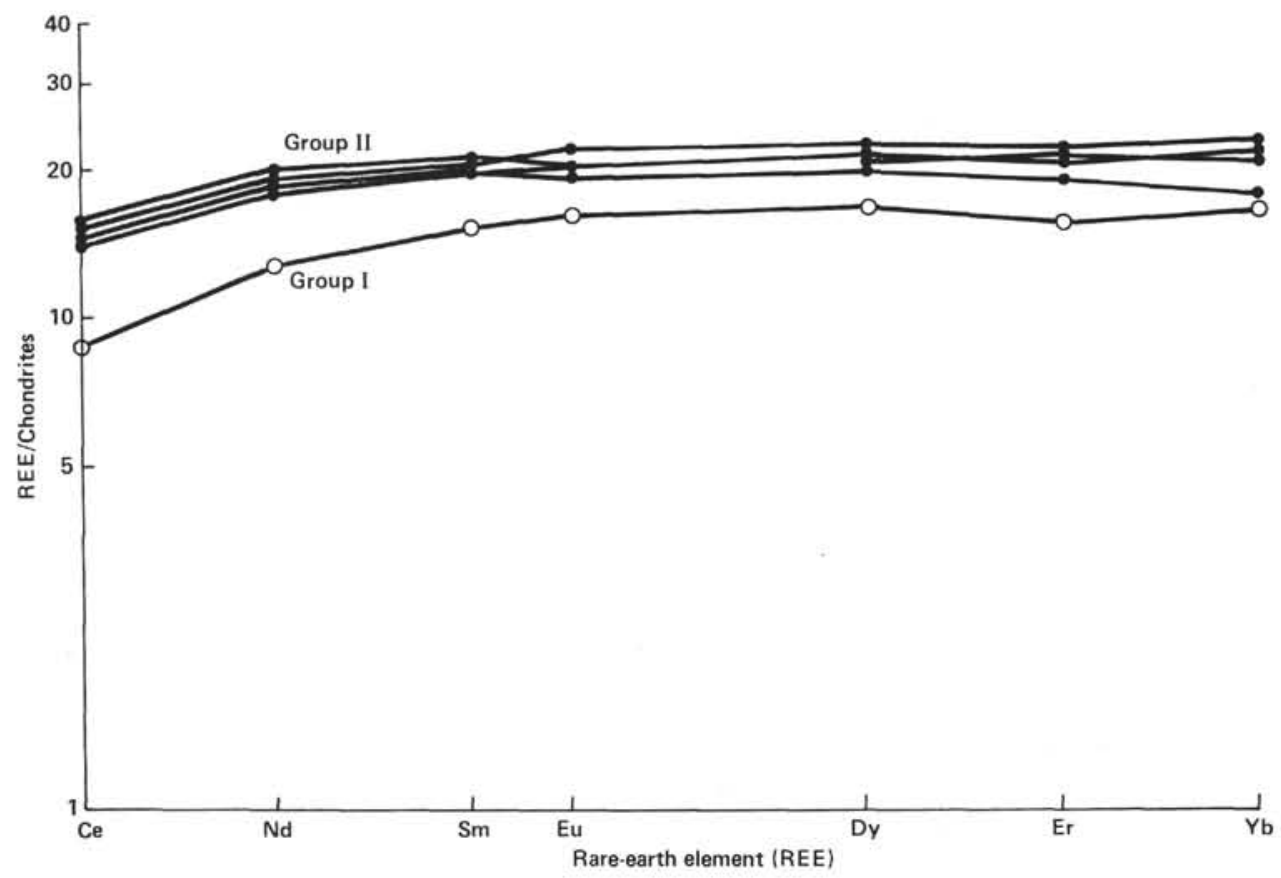

Figure 2. Chondrite normalized rare-earth element (REE) abundances of samples from Hole 581. The Group II samples have been separated slightly for clarity (REE abundances are given in Table 2). Note the lower $\mathrm{Ce} / \mathrm{Yb}$ ratio of Sample B, a Group I sample, than the Group II samples.

1980; Langmuir et al., 1977). Fractionation of $\mathrm{Ce} / \mathrm{Yb}$ ratios of the magnitude found in this study have been reported for basalts from the Franco-American Mid Ocean Undersea Study (FAMOUS) area by Langmuir et al. (1977). Although such fractionation cannot be produced by batch melting, Langmuir et al. (1977) have shown it may be produced by dynamic melting, a process that involves multistage melting of a mantle source with partial retention of the initial melt in the source.

The abundance of $\mathrm{Ce}$ and $\mathrm{Zr}$ predicted by the model is slightly lower than the observed abundances, while the depletion calculated for $\mathrm{Ni}$ and $\mathrm{Cr}$ is in good agree- 
Table 3. Summary of fractional crystallization models.

\begin{tabular}{cllcc}
\hline Parent & Daughter & \multicolumn{1}{c}{ Minerals } & $\begin{array}{c}\text { Percent } \\
\text { removed }\end{array}$ & $\begin{array}{c}\text { Sum of the } \\
\text { residuals }\end{array}$ \\
\hline Group I & \multirow{2}{*}{ Group II* } & Olivine (Fo 86) & 3.08 & 0.01 \\
& & $\begin{array}{l}\text { Augite (\#1) } \\
\text { Plagioclase (An 71) }\end{array}$ & 10.69 & \\
Primitive & Group I & Olivine (Fo 86) & 2.78 & \multirow{2}{*}{0.5} \\
MORB & & Augite (\#2) & 24.32 & \\
Group II & \multirow{2}{*}{ Site 304 } & Plagioclase (An 85) & 17.63 & \\
& & Olivine (Fo 83) & 5.75 & \multirow{2}{*}{0.87} \\
& & Augite (\#1) & 3.81 & \\
& & Plagioclase (An 71) & 26.57 & \\
\hline
\end{tabular}

Mineral compositions used in models.

\begin{tabular}{|c|c|c|c|c|c|c|}
\hline Oxide & $\begin{array}{l}\text { Olivine } \\
\text { (Fo 86) }\end{array}$ & $\begin{array}{l}\text { Olivine } \\
\text { (Fo 83) }\end{array}$ & $\begin{array}{c}\text { Augite } \\
\# 1\end{array}$ & $\begin{array}{c}\text { Augite } \\
\# 2\end{array}$ & $\begin{array}{l}\text { Plagioclase } \\
\text { (An 71) }\end{array}$ & $\begin{array}{l}\text { Plagioclase } \\
\text { (An 85) }\end{array}$ \\
\hline $\mathrm{SiO}_{2}$ & 39.87 & 40.8 & 52.68 & 50.90 & 53.78 & 49.33 \\
\hline $\mathrm{TiO}_{2}^{2}$ & 0.0 & 0.0 & 0.52 & 0.9 & 0.0 & 0.0 \\
\hline $\mathrm{Al}_{2} \mathrm{O}_{3}$ & 0.0 & 0.0 & 2.29 & 2.86 & 28.35 & 33.00 \\
\hline $\mathrm{FeO}$ & 13.97 & 14.6 & 10.39 & 15.03 & 0.0 & 0.47 \\
\hline $\mathrm{MnO}$ & 0.23 & 0.14 & 0.0 & 0.32 & 0.7 & 0.0 \\
\hline $\mathrm{MgO}$ & 45.38 & 46.0 & 16.95 & 16.12 & 0.2 & 0.0 \\
\hline $\mathrm{CaO}$ & 0.18 & 0.3 & 17.08 & 13.08 & 12.82 & 16.50 \\
\hline $\mathrm{Na}_{2} \mathrm{O}$ & 0.0 & 0.0 & 0.0 & 0.54 & 4.2 & 1.78 \\
\hline $\mathrm{K}_{2} \mathrm{O}$ & 0.0 & 0.0 & 0.0 & 0.0 & 0.0 & 0.0 \\
\hline $\mathrm{P}_{2} \mathrm{O}_{5}$ & 0.0 & 0.0 & 0.0 & 0.0 & 0.0 & 0.0 \\
\hline Source: & $\begin{array}{l}\text { Clague } \\
\text { and } \\
\text { Bunch } \\
(1976)\end{array}$ & $\begin{array}{l}\text { Average } \\
\text { of } \\
\text { several }\end{array}$ & $\begin{array}{l}\text { Mattey } \\
\text { and } \\
\text { Muir } \\
\text { (1980) }\end{array}$ & $\begin{array}{c}\text { Thompson } \\
\text { and } \\
\text { Humphris } \\
(1980)\end{array}$ & $\begin{array}{c}\text { Thompson } \\
\text { and } \\
\text { Humphris } \\
(1980)\end{array}$ & $\begin{array}{l}\text { Mattey } \\
\text { and Muir } \\
(1980)\end{array}$ \\
\hline
\end{tabular}

Rock compositions.

\begin{tabular}{lrrcc}
\hline Oxide & Group I & Group II* & Primitive & Site 304 \\
\hline $\mathrm{SiO}_{2}$ & 50.05 & 49.67 & 50.3 & 49.56 \\
$\mathrm{TiO}_{2}$ & 1.34 & 1.83 & 0.93 & 2.07 \\
$\mathrm{Al}_{2} \mathrm{O}_{3}$ & 16.14 & 15.92 & 15.6 & 13.05 \\
$\mathrm{FeO}$ & 7.95 & 9.38 & 8.59 & 12.68 \\
$\mathrm{MnO}$ & 0.15 & 0.20 & 0.14 & 0.22 \\
$\mathrm{MgO}$ & 8.27 & 7.50 & 9.80 & 6.57 \\
$\mathrm{CaO}$ & 10.93 & 10.16 & 12.77 & 10.6 \\
$\mathrm{Na}{ }_{2} \mathrm{O}$ & 2.81 & 3.01 & 2.41 & 2.78 \\
$\mathrm{~K}_{2} \mathrm{O}$ & 0.25 & 0.35 & 0.05 & 0.08 \\
$\mathrm{P}_{2} \mathrm{O}_{5}$ & 0.11 & 0.17 & 0.09 & 0.22 \\
$\mathrm{Source}:$ & & & Batiza & Marshall \\
& & & et al. & $(1975)$ \\
& & & $(1977)$ & \\
\hline
\end{tabular}

Note: Group $\mathrm{II}^{*}$ is an average of Samples C, E, G, H, and $\mathrm{L}$, the Group II samples with the highest $\mathrm{TiO}_{2}$. Results for an average of the entire Group II yields nearly identical results, with higher residuals due to $\mathrm{CaO}$, which is always low in the calculated models. The error of $\mathrm{TiO}_{2}$ is also larger using the average of the entire group, thus we believe the average of the high $\mathrm{TiO}_{2}$ samples, which are presumably the most fractionated, is more appropriate for modeling the extent of fractionation. The "primitive" analysis represents the least-fractionated MORB found associated with the ferrobasalts of the Siqueros Fracture Zone (Batiza et al., 1977). Models were calculated using the least-squares method of Wright and Doherty (1970).

ment with observed values. The scatter in $\mathrm{Rb}$ and $\mathrm{Sr}$ data is too large for meaningful numerical evaluation.

Comparison of Hole 581 samples to other MORBs from the Northwest Pacific (Sites 303, 304, and 307) is complicated by the considerable alteration of all samples from the other sites (Table 4). The least altered sample from Site 303 has nearly $4 \%$ total water, the least altered sample from Site 307 has $3 \%$, and both have a highly altered groundmass (Marshall, 1975). Site 304 samples are clearly more fractionated than Hole 581 samples, and the differences in composition (higher $\mathrm{FeO}$ and
Table 4. Comparison of the average composition of Hole 581 samples to other MORB suites.

\begin{tabular}{|c|c|c|c|c|c|c|c|}
\hline Oxide & $\begin{array}{c}\text { Group } \\
1, \\
\text { Hole } \\
581\end{array}$ & $\begin{array}{c}\text { Group } \\
\text { II, } \\
\text { Hole } \\
581\end{array}$ & $\begin{array}{l}\text { Site } \\
303 \text {, } \\
\text { Hole } \\
303 \mathrm{~A}\end{array}$ & $\begin{array}{c}\text { Site } \\
304, \\
\text { Hole } \\
304\end{array}$ & $\begin{array}{c}\text { Site } \\
307, \\
\text { Hole } \\
307\end{array}$ & $\begin{array}{c}\text { Average } \\
\text { EPR }\end{array}$ & $\begin{array}{l}\text { Average } \\
\text { MORB }\end{array}$ \\
\hline $\mathrm{SiO}_{2}$ & 50.82 & 50.32 & 51.35 & 50.65 & 52.04 & 50.19 & 50.53 \\
\hline $\mathrm{TiO}_{2}$ & 1.36 & 1.82 & 3.26 & 2.11 & 1.66 & 1.77 & 1.56 \\
\hline $\mathrm{Al}_{2} \mathrm{O}_{3}$ & 16.39 & 15.99 & 15.11 & 13.33 & 15.74 & 14.86 & 15.27 \\
\hline $\mathrm{FeO}$ & 8.08 & 9.49 & 9.10 & 12.96 & 9.75 & 11.33 & 10.46 \\
\hline $\mathrm{MnO}$ & 0.15 & 0.20 & 0.19 & 0.22 & 0.16 & - & - \\
\hline $\mathrm{MgO}$ & 8.40 & 7.58 & 6.39 & 6.71 & 5.66 & 7.10 & 7.47 \\
\hline $\mathrm{CaO}$ & 11.10 & 10.57 & 10.59 & 10.83 & 11.36 & 11.44 & 11.49 \\
\hline $\mathrm{Na}_{2} \mathrm{O}$ & 2.85 & 3.00 & 3.22 & 2.84 & 2.85 & 2.66 & 2.62 \\
\hline $\mathrm{K}_{2} \mathrm{O}$ & 0.25 & 0.36 & 0.40 & 0.08 & 0.62 & 0.16 & 0.16 \\
\hline $\mathrm{P}_{2} \mathrm{O}_{5}$ & 0.11 & 0.17 & 0.33 & 0.22 & 0.18 & 0.14 & 0.13 \\
\hline Source: & $\begin{array}{l}\text { This } \\
\text { paper }\end{array}$ & $\begin{array}{l}\text { This } \\
\text { paper }\end{array}$ & $\begin{array}{c}\text { Marshall } \\
(1975)\end{array}$ & $\begin{array}{c}\text { Marshall } \\
\text { (1975) }\end{array}$ & $\begin{array}{l}\text { Marshall } \\
\text { (1975) }\end{array}$ & $\begin{array}{l}\text { Melson } \\
\text { et al. } \\
\text { (1976) }\end{array}$ & $\begin{array}{l}\text { Melson } \\
\text { et al. } \\
\text { (1976) }\end{array}$ \\
\hline
\end{tabular}

Note: All samples have been recalculated on an anhydrous basis, with total iron as $\mathrm{FeO}$ Group I includes Samples A and B, Group II is the average of all other samples in this study. Site 303, 304, and 307 analyses are representative analyses, not averages, because of the extensive alteration of most samples from these holes (Marshall, 1975). Average EPR is an average of basaltic glasses from the East Pacific Rise, Average MORB is an average of over 500 MORB glasses (Melson et al. 1976).

$\mathrm{TiO}_{2}$ and lower $\mathrm{MgO}$ ) are those expected from fractionation. Only the lower $\mathrm{Al}_{2} \mathrm{O}_{3}$ contents of Site 304 samples would not be expected from fractionation. A magma of the composition of the Site 304 sample may be derived from a magma with the average composition of Group II samples by the removal of $26 \%$ plagioclase, $6 \%$ olivine, and $4 \%$ augite (Table 3 ), although the validity of such models, considering the extent of alteration of the Site 304 samples, is problematic. Samples from Sites 303 and 307 differ from Hole 581 samples only in lower $\mathrm{MgO}$ and $\mathrm{Al}_{2} \mathrm{O}_{3}$ contents, and the higher $\mathrm{TiO}_{2}$ content in samples from Site 303. The differences in $\mathrm{MgO}$ are attributable to alteration, and the high $\mathrm{TiO}_{2}$ values in Site 303 samples are not observed at Sites 304 and 307 . Thus, the only consistent differences in composition between Hole 581 samples and samples from Sites 303,304 , and 307 that are not attributable to fractionation or alteration are the $\mathrm{Al}_{2} \mathrm{O}_{3}$ contents. In view of the extreme alteration of the samples from Sites 303 and 307 , no fractionation models were calculated for these sites.

Comparison to samples from the East Pacific Rise (EPR) and to average MORBs (Table 4) shows that the average composition of Hole 581 rocks is typical for slightly fractionated MORBs, with a slightly higher than average $\mathrm{Al}_{2} \mathrm{O}_{3}$ content. The composition of each of the samples in this study is within the range of EPR basalts (Melson et al. 1976). However, the $\mathrm{FeO} * / \mathrm{MgO}$ ratio is slightly lower than samples with the same $\mathrm{TiO}_{2}$ content from other areas (Fig. 3).

\section{CONCLUSIONS}

The samples from Hole 581 are slightly fractionated MORBs with higher than average $\mathrm{Al}_{2} \mathrm{O}_{3}$ contents. The more evolved Group II samples could have been derived from a magma with the average composition of the more primitive Group I samples by the crystallization of $18 \%$ plagioclase, $10 \%$ augite, and $3 \%$ olivine. However, traceelement models require a greater amount of fractionation to produce the observed enrichment of $\mathrm{Ce}$ and $\mathrm{Zr}$ in 


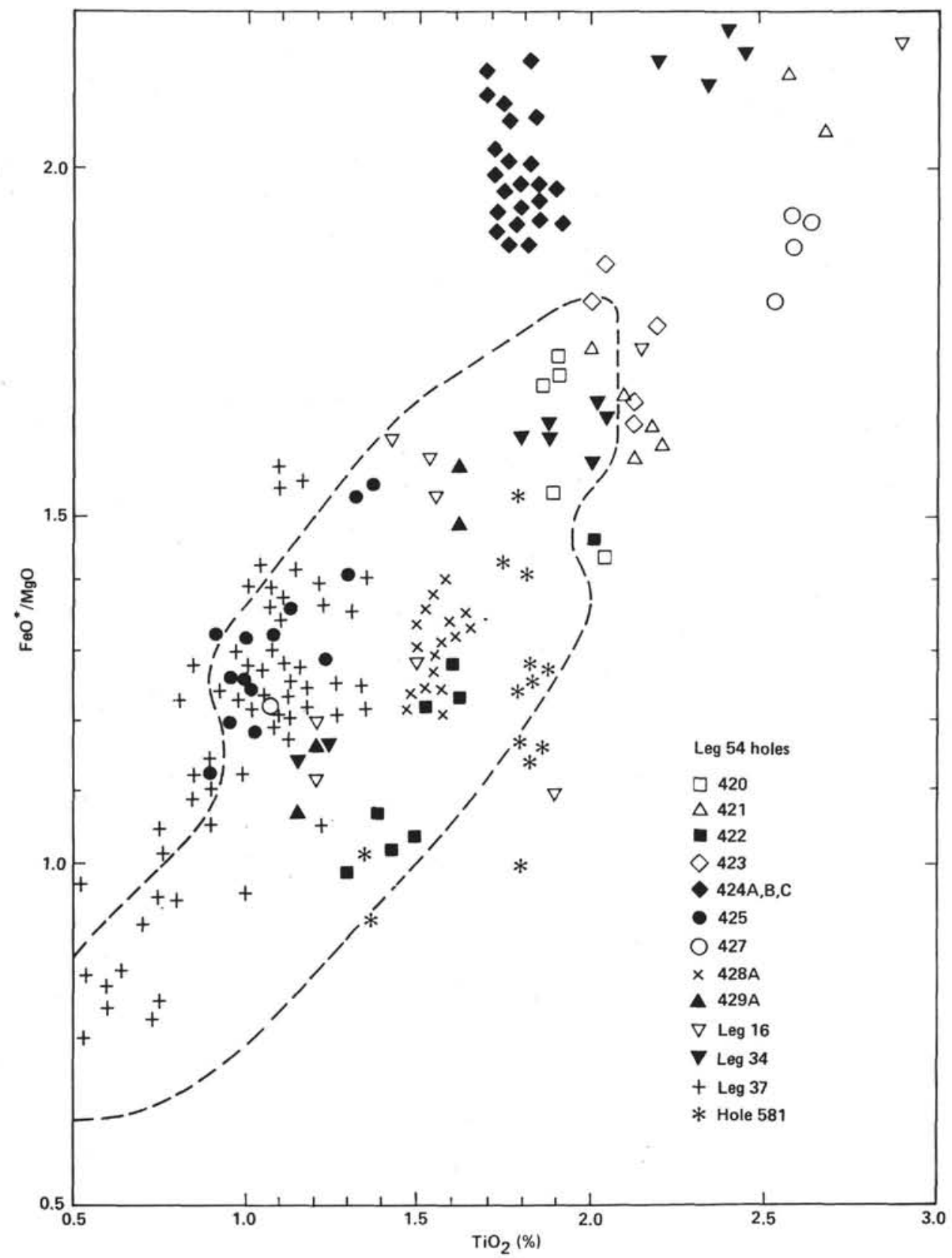

Figure 3. A plot of $\mathrm{FeO}^{*} / \mathrm{MgO}$ versus $\mathrm{TiO}_{2}$ comparing Hole 581 samples to other MORBs from the Pacific Ocean (the figure, including all data points other than Hole 581 samples, is from Srivastava et al., 1980). Note the generally lower $\mathrm{FeO}^{*} / \mathrm{MgO}$ ratios for the Hole 581 samples than for other MORBs. The presence of several of the Hole 581 samples on the main trend is believed to be due to alteration, since the samples that are near the main trend are among the most altered of the samples, while the least altered samples all lie well below the main trend. Alteration would be expected to move samples nearly vertically on the plot, since alteration will increase $\mathrm{FeO}^{*}$, decrease $\mathrm{MgO}$, and not significantly change $\mathrm{TiO}_{2}$ (Marshall, 1975; Humphris et al., 1980).

Group II samples. The large increase in $\mathrm{Ce} / \mathrm{Yb}$ ratios between Group I and Group II samples could not have resulted from fractional crystallization, nor could it have been produced by different amounts of partial melting of a homogeneous source. The change in $\mathrm{Ce} / \mathrm{Yb}$ ratio requires a more complex process such as dynamic melting, if all Hole 581 samples were derived from the same source. The Hole 581 rocks are thus typical slightly fractionated basalts such as are common at fast-spreading ridges and propagating rifts (Melson et al., 1976; Natland, 1980; Christie and Sinton, 1981).

\section{REFERENCES}

Arth, J. G., and Hanson, G. N., 1975. Geochemistry and origin of the early Precambrian crust of northeastern Minnesota. Geochim. Cosmochim. Acta, 39:325-362.

Batiza, R., Rosendahl, B. R., and Fisher, R. L., 1977. Evolution of Oceanic Crust, 3, Petrology and chemistry of basalts from the East 
Pacific Rise and the Siqueiros Transform Fault. J. Geophys. Res., $82: 265-277$.

Christie, D. M., and Sinton, J. M., 1981. Evolution of abyssal lavas along propagating segments of the Galapagos Spreading Center. Earth Planet. Sci. Lett., 56:321-335.

Clague, D. A., and Bunch, T. E., 1976. Formation of ferrobasalt at East Pacific midocean spreading centers. J. Geophys. Res., 81: 4247-4256.

Clemency, C. V., and Borden, D. L., 1978. The precision of "rapid" rock analyses and the homogeneity of new U.S.G.S. standard rock samples. Geostandards Newsl., 2:147-155.

Gast, P. W., 1968. Trace element fractionation and the origin of tholeiitic and alkaline magma types. Geochim, Cosmochim, Acta, 32: 1057-1086.

Humphris, S. E., Thompson, R. N., Gibson, I. L, and Marriner, G. F., 1980. Comparison of geochemistry of basalts from the East Pacific Rise, OCP Ridge and Siqueiros Fracture Zone, Deep Sea Drilling Project Leg 54. In Rosendahl, B. R., Hekinian, R., et al., Init. Repts. DSDP, 54: Washington (U.S. Govt. Printing Office), 635-650.

Langmuir, C. H., Bender, J. F., Bence, A. E., and Hanson, G. N., 1977. Petrogenesis of basalts from the FAMOUS area; Mid-Atlantic Ridge. Earth Planet. Sci. Lett., 36:133-156.

Larson, R. L., and Chase, C. G., 1972. Late Mesozoic evolution of the Western Pacific Ocean. Geol. Soc. Am. Bull., 83:3627-3644.

Marshall, M., 1975. Petrology and chemical composition of basaltic rocks recovered on Leg 32, Deep Sea Drilling Project. In Larson, R. L., Moberly, R., et al., Init. Repts. DSDP, 32: Washington (U.S. Govt. Printing Office), 563-570.

Mattey, D. P., and Muir, I. D., 1980. Geochemistry and mineralogy of basalts from the Galapagos Spreading Center, Deep Sea Drilling Project Leg 54. In Rosendahl, B. R., Hekinian, R., et al., Init. Repts. DSDP, 54: Washington (U.S. Govt. Printing Office), 755-772.

Melson, W. G., Vallier, T. L., Wright, T. L., Byerly, G., and Nelsen, J., 1976. Chemical diversity of abyssal volcanic glass erupted along Pacific, Atlantic and Indian Ocean sea-floor spreading centers. In Sutton, G. H., Manghnani, M. H., and Moberly, R. (Eds.), The
Geophysics of the Pacific Ocean Basin and its Margins: Washington D.C. (American Geophysical Union), 19:351-367.

Moberly, R., and Larson, R. L., 1975. Mesozoic magnetic anomalies, ocean plateaus and seamount chains in the northwestern Pacific Ocean. In Larson, R. L., Moberly, R., et al., Init. Repts. DSDP, 32: Washington (U.S. Govt. Printing Office), 945-957.

Natland, J. H., 1980. Effects of axial magma chambers beneath spreading centers on the compositions of basaltic rocks. In Rosendahl, B. R., Hekinian, R., et al., Init. Repts. DSDP, 54: Washington (U.S. Govt. Printing Office, 833-850.

Schilling, J.-G., Anderson, R. N., and Vogt P., 1976. Rare earth, Fe and $\mathrm{Ti}$ variations along the Galapagos spreading center, and their relationship to the Galapagos mantle plume. Nature (London), 261: 108-113.

Shapiro, L., 1975. Rapid analysis of silicate, carbonate and phosphate rocks, revised edition. Geol. Surv. Bull. (U.S.), 1401:1-76.

Srivastava, R. K., Emmerman, R., and Puchelt, H., 1980. Petrology and geochemistry of basalts from Deep Sea Drilling Project Leg 54. In Rosendahl, B. R., Hekinian, R., et al., Init. Repts DSDP, 54, Washington (U.S. Govt. Printing Office), 671-694.

Sun, S.-S., Nesbitt, R. G., and Sharaskin, A. Y., 1979. Geochemical characteristics of mid-ocean ridge basalts. Earth Planet. Sci. Lett., 44:119-138.

Thompson, R. N., and Humphris, S. E., 1980. Silicate mineralogy of basalts from the East Pacific Rise, OCP Ridge, and Siqueiros Fracture Zone: Deep Sea Drilling Project Leg 54. In Rosendahl, B. R., Hekinian, R., et al., Init. Repts. DSDP, 54: Washington (U.S. Govt. Printing Office), 651-667.

Vocke, R. D., 1983. Petrogenetic modelling in an archean gneiss terrain, Saglek, northern Labrador [Ph.D. dissert.]. State University of New York, Stony Brook, New York.

Wright, T. L., and Doherty, P. C., 1970. A linear programming and least squares computer method for solving petrologic mixing problems. Geol. Soc. Am. Bull., 81:1995-2007.

Date of Initial Receipt: 21 February 1984

Date of Acceptance: 12 November 1984 